\title{
TRANSFORMASI PENGATURAN PERDAGANGAN JASA PERAWAT : PERSPEKTIF GENERAL AGREEMENT ON TRADE IN SERVICE BERDASARKAN UNDANG-UNDANG NOMOR 38 TAHUN 2014 TENTANG KEPERAWATAN
}

\author{
Junia Adolfina Blegur Laumuri \\ Fakultas Hukum Universitas Udayana \\ juniaadolfina@ymail.com
}

\begin{abstract}
The ASEAN Economic Community (AEC) not only opens the flow of trade in goods but also the professional labor market, including nurses. Therefore, to regulate the trade liberalization of nursing services in ASEAN, MRA on Nursing Services was formed with the aim of facilitating the transfer of professional nurses between ASEAN countries by examining the use of transformation theories related to the trade of nursing services from the perspective of international agreements based on Act No. 38 Year 2014 concerning Nursing. This study aims to find clarity regarding the transformation of the trade arrangements of nursing services related to MRA on Nursing Services in Law Number 38 Year 2014 concerning Nursing. The research method in this research is the normative legal research method with using the statue approach and the conceptual approach. The results of the study show that the regulation of trade liberalization of nursing services specifically related to nurses is permitted and can be done by fulfilling the principles set out in GATS namely in Article 1, Article VI paragraph (4) and in Article VII GATS and the absence of nursing counseling in Indonesia does not only ignore the provisions in Article 63 of the Nursing Law can also potentially hamper the implementation of MRA on nursing services in Indonesia, particularly in relation to Article III MRA on nursing services, therefore the transformation of provisions regarding the trade of nurse services cannot be carried out optimally in accordance with the context of MRA on nursing services.
\end{abstract}

Keywords : Trade in Services, Nurse, GATS, Mutual Recognition Arrangements

\begin{abstract}
Abstrak
ASEAN Economic Community (AEC) tidak hanya menciptakan pasar melalui perdagangan barang tetapi juga pasar tenaga kerja profesional, termasuk perawat. Oleh karena itu untuk mengatur liberalisasi perdagangan jasa keperawatan di ASEAN maka dibentuk MRA on Nursing Services dengan tujuan untuk memfasilitasi perpindahan tenaga profesional perawat antar negara ASEAN dengan mengkaji menggunakan teori transformasi terkait perdagangan jasa perawat dari perspektif perjanjian internasional berdasarkan Undang-Undang Nomor 38 Tahun 2014 Tentang Keperawatan. Tujuan dari Penelitian ini adalah untuk menemukan kejelasan mengenai transformasi pengaturan perdagangan jasa perawat terkait MRA on Nursing Services dalam Undang-Undang Nomor 38 Tahun 2014 Tentang Keperawatan. Adapun metode penelitian dalam penelitian ini adalah metode penelitian hukum normatif dengan pendekatan undang-undang dan pendekatan konseptual. Hasil studi menunjukkan bahwa pengaturan liberalisasi perdagangan jasa keperawatan khususnya terkait tenaga perawat diperbolehkan dan dapat dilakukan dengan memenuhi prinsip-prinsip yang diatur dalam GATS yakni dalam Pasal 1, Pasal VI
\end{abstract}

Junia Adolfina Blegur Laumuri, Transformasi Pengaturan Perdagangan Jasa Perawat : Perspektif GATS Berdasarkan Undang-Undang Nomor 38 Tahun 2014 Tentang Keperawatan 
ayat (4) dan dalam Pasal VII GATS dan belum terbentunya konsil keperawatan di Indonesia tidak hanya mengabaikan ketentuan dalam Pasal 63 UU Keperawatan tetapi juga dapat berpotensi menghambat pelaksanaan MRA on nursing services di Indonesia khususnya terkait Article III MRA on nursing services, oleh karena itu pelaksanaan transformasi ketentuan tentang perdagangan jasa perawat belum dapat dilakukan secara maksimal sesuai dengan konteks MRA on nursing services.

Kata kunci: Perdagangan Jasa, Perawat, GATS, Mutual Recognition Arrangements

\section{PENDAHULUAN}

Globalisasi dan liberalisasi dalam perdagangan jasa di kawasan Association of Southeast Asian Nations (ASEAN) dalam kerangka ASEAN Economic Community (AEC) dimulai dari diberlakukannya ASEAN Framework Agreement on Services (AFAS) yang merupakan instrumen dalam rangka kerjasama terkait liberalisasi perdagangan di bidang jasa antar negara ASEAN. Berdasarkan Article 5 AFAS setiap negara anggota ASEAN dapat mengakui pendidikan ataupun pengalaman, kualifikasi, lisensi atau sertifikasi dari negara anggota ASEAN lainnya, dengan tujuan untuk melisensi atau mensertifikasi pemasok layanan. Pengakuan sebagaimana dimaksud dalam Article 5 AFAS tersebut dapat didasarkan melalui persetujuan (agreement) ataupun pengaturan (arrangement) antar negara anggota terkait atau dapat diberlakukan dengan cara mandiri. Realisasi dari Article 5 AFAS tersebut direalisasikan melalui dibuatnya program Mutual Recognition Arrangements (MRA) pada tahun 1996. MRA merupakan kesepakatan mengenai kualifikasi tenaga profesional dalam bidang pelayanan jasa dengan tujuan memfasilitasi kemudahan perpindahan atau mekanisme pasar tenaga terampil atau professional di kawasan negara-negara ASEAN termasuk tenaga perawat dan untuk mendukung liberalisasi pada sektor jasa keperawatan di kawasan ASEAN, khususnya terkait perdagangan jasa perawat di kawasan ASEAN, negara-negara anggota ASEAN termasuk Indonesia telah menyetujui dan menandatangani MRA on Nursing Services pada 8 Desember 2006.

Tujuan MRA on Nursing Services adalah memfasilitasi perpindahan tenaga profesional perawat antar negara ASEAN, melakukan penukaran informasi dan keahlian pada standar dan kualifikasi, mempromosikan "best practise" pada pelayanan profesional perawat dan menyediakan kesempatan untuk meningkatkan kemampuan dan pelatihan perawat. ${ }^{1}$ Beberapa hal yang

${ }^{1}$ Rahmi Yuningsih. Dampak Mutual Recognition Arrangement (MRA) on Nursing Services Terhadap Profesi Perawat Indonesia. Jurnal Aspirasi Pusat Pengkajian Pengolahan Data dan Informasi Sekretariat Jenderal DPR RI, 3(2), 2012, hlm. 187.

Junia Adolfina Blegur Laumuri, Transformasi Pengaturan Perdagangan Jasa Perawat : Perspektif GATS Berdasarkan Undang-Undang Nomor 38 Tahun 2014 Tentang Keperawatan 
mendasari tentang MRA termasuk MRA on Nursing Services antara lain:2 keharusan negara tujuan atau negara penerima mengakui standar kualifikasi untuk menopang liberalisasi di sektor tenaga profesional atau terampil serta pelatihan-pelatihan yang didapatkan dari negara asal tenaga profesional; negara asal dari tenaga kerja profesional mempunyai kewenangan untuk menerima serta mengesahkan standar kualifikasi termasuk pelatihan dengan cara memberikan gelar diploma maupun sertifikat; pengakuan standar kualifikasi dari negara asal tenaga kerja profesional tidaklah berlaku secara otomatis.

Hak tenaga kerja profesional atau terampil khususnya perawat tidak secara otomatis diberikan hak berdasarkan MRA on Nursing Services untuk menjalankan suatu profesi tetapi juga untuk menetapkan standarisasi dan persyaratan - persyaratan lain baik yang diterapkan di negara penerima ataupun negara asal. Pengakuan di negara asal pun tidak menjamin tenaga kerja profesional akan mendapat akses pasar, karena perawat juga harus memenuhi persyaratan yang diatur berdasarkan peraturan yang berlaku dinegara tujuan agar diakui untuk melakukan praktik di negara tersebut.

Penilaian jasa keperawatan Indonesia terkait persaingan dalam pasar ASEAN dilihat dari persepektif kualitas dan kuantitas, terkait dengan kualitas, kelemahan tenaga perawat Indonesia dalam menggunakan bahasa asing perlu untuk mendapatkan perhatian dari pemerintah, ${ }^{3}$ oleh karena itu untuk meningkatkan daya saing tenaga kerja Indonesia di pasar ASEAN, pemerintah Indonesia mengambil peran penting dalam melakukan perbaikan terhadap kualitas sumber daya manusia tenaga kerja khususnya tenaga kerja profesional di Indonesia, dimana pembekalan dalam hal peningkatan kualitas tenaga kerja profesional di Indonesia tidak hanya dalam hal keahlian, pendidikan serta produktifitas tetapi penting juga pembekalan terkait kemampuan dalam bahasa asing bagi tenaga kerja Indonesia. ${ }^{4}$ Selain dari pada itu, belum adanya ketentuan baku terkait standar nasional terhadap profesi perawat dan kebijakan-kebijakan terkait profesi perawat yang dibuat pemerintah Indonesia masih tumpang tindih, misalnya dalam hal sertifikasi dan jenjang pendidikan perawat termasuk dalam faktor-faktor yang memperlemah posisi Indonesia, 5 belum dibentuknya Konsil Keperawatan

${ }^{2}$ Makmur Keliat, dkk. Pemetaan Pekerja Terampil Indonesia dan Liberalisasi Jasa ASEAN. ASEAN Study Center Fakultas Imu Sosial dan Ilmu Politik Universitas Indoensia, 2013. hlm. 10.

${ }^{3}$ Solehuddin. Perlindungan Hukum Terhadap Perawat Dalam Menghadapi ASEAN Economic Community (AEC). Jurnal Hukum Fakultas Hukum Universitas Brawijaya, 2015. hlm. 4.

${ }^{4}$ Anung Pramudyo. Mempersiapkan Sumber Daya Manusia Indonesia dalam Menghadapi Masyarakat Ekonomi ASEAN Tahun 2015. Jurnal Bisnis Manajemen dan Akuntansi Akademi Manajemen Administrasi YPK Yogyakarta, 2(2), 2014. hlm. 96.

5Solehuddin, op.cit, hlm. 4-5.

Junia Adolfina Blegur Laumuri, Transformasi Pengaturan Perdagangan Jasa Perawat : Perspektif GATS Berdasarkan Undang-Undang Nomor 38 Tahun 2014 Tentang Keperawatan 
serta belum adanya pengaturan teknis atau peraturan pelaksana yakni peraturan pemerintah maupun peraturan menteri untuk mengatur secara jelas tentang keperawatan khususnya mengenai profesi perawat. Sedangkan dalam hal kuantitas, adanya perbedaan antara kebutuhan dan ketersediaan sumber daya manusia khususnya perawat, yang menjadi persoalan bukan hanya terkait pemenuhan tenaga kerja perawat untuk bekerja diluar negeri dalam hal untuk meningkatkan daya saing tetapi termasuk juga untuk pemenuhan kebutuhan tenaga perawat dalam negeri.

Studi sebelumnya yang juga mengkaji tentang perdagangan jasa khususnya perdagangan jasa perawat, namun fokusnya berbeda diantaranya: studi yang dilakukan oleh Solehuddin yang mengkaji "Perlindungan Hukum Terhadap Perawat Dalam Menghadapi Asean Economic Community (AEC)," kajian tersebut lebih menitik beratkan pada masalah ketenagakerjaan khususnya perlindungan hukum terhadap profesi perawat dalam menghadapi AEC. Selain itu, Rahmi Yuningsih mengkaji "Dampak Mutual Recognition Arrangement (MRA) On Nursing Services Terhadap Profesi Perawat Indonesia" namun dengan penekanan pada dampak MRA on Nursing Services sebelum diundangkannya Undang-Undang Nomor 38 Tahun 2014 Tentang Keperawatan (UU Keperawatan). Sementara itu dalam tulisan ini fokus kajiannya transformasi pengaturan MRA on Nursing Services dalam UU Keperawatan, dimana penelitian ini bertujuan untuk menemukan kejelasan mengenai transformasi pengaturan perdagangan jasa perawat terkait MRA on Nursing Services dalam UU Keperawatan.

\section{METODE PENELITIAN}

Metode penelitian dalam penelitian ini yaitu metode penelitian hukum normatif, dimana dalam penelitian hukum normatif yang menjadi objek dari penelitian adalah sistem norma, yang dimaksud dengan sistem norma ialah terkait dengan asas, norma, kaidah dari peraturan perundang-undangan, termasuk pula putusan pengadilan dan perjanjian, serta doktrin. ${ }^{6}$

Pendekatan yang digunakan adalah pendekatan undang-undang (statue approach), yang dilakukan dengan menelaah permasalahan yang dibahas dalam penelitian ini menggunakan peraturan perundang-undangan yang berlaku dan pendekatan konseptual (conceptual approach), yang dilakukan dengan menganalisis permasalahan yang dibahas dalam penelitian ini berdasarkan asas, konsep, maupun teori.

\section{HASIL DAN PEMBAHASAN}

6Mukti Fajar dan Yulianto AchmadDualisme Penelitian Hukum-Normatif dan Empiris. Yogyakarta: Pustaka Pelajar, 2015. hlm. 34.

Junia Adolfina Blegur Laumuri, Transformasi Pengaturan Perdagangan Jasa Perawat : Perspektif GATS Berdasarkan Undang-Undang Nomor 38 Tahun 2014 Tentang Keperawatan 


\section{Pengaturan Perdagangan Jasa Keperawatan dalam General Agreement On Trade In Service}

Liberalisasi perdagangan jasa antara negara-negara ASEAN berpedoman pada instrument hukum yakni, AFAS yang merupakan instrumen pengendalian untuk mengatur liberalisasi perdagangan jasa dalam konteks regional antara negara-negara anggota ASEAN, dan General Agreement on Trade in Service (GATS) sebagai suatu instrumen internasional yang mengatur liberalisasi perdagangan jasa antara negaranegara yang manandatangani dan meratifikasi perjanjian World Trade Organization (WTO) dimana negara anggota ASEAN juga merupakan negara anggota WTO sehingga sepatutnya menghormati dan melaksanakan ketentuan-ketentuan yang diatur oleh WTO dalam GATS. Seluruh ketentuan dalam AFAS pada hakekatnya konsisten dan sejalan dengan perjanjian internasional terkait perdagangan jasa yang ditetapkan oleh WTO dalam GATS, namun dalam AFAS anggota ASEAN didorong agar memberikan tingkat kesungguhan terkait komitmen yang lebih besar antara anggota ASEAN dibandingkan dengan komitmen mereka dalam GATS, dan membuka lebih banyak sektor maupun subsektor, oleh karena itu maka AFAS dikenal juga dengan istilah GATS Plus. ${ }^{7}$

Final Act dari Uruguay Round, yang mencakup kedalamnya pengaturan tentang perdagangan jasa. ${ }^{8}$ Dalam Pasal I ayat (2) GATS perdagangan jasa didefinisikan sebagai berikut: ${ }^{9}$ (a) Jasa yang diberikan dari satu wilayah atau teritori negara perserta ke wilayah atau teritori negara peserta lainnya; (b) Jasa yang diberikan dalam satu wilayah atau teritori negara kepada konsumen dari wilayah atau teritori negara peserta lainnya; (c) Jasa yang diberikan berdasarkan kehadiran badan usaha satu negara dalam wilayah atau teritori negara lainnya; (d) Jasa yang diberikan oleh warga negara satu negara peserta dalam wilayah atau teritori negara peserta lainnya.Dalam pengertian "jasa" pada Pasal I ayat (2) GATS diatas yakni segala sektor kecuali jasa-jasa yang diberikan dalam pelaksanaan pemerintah dimaksud setiap jasa yang diberikan tidak secara komersial atau tidak secara berkompetisi dengan pemberi jasa lainnya. ${ }^{10}$

Dalam melaksanakan kewajiban dan komitmen berdasarkan GATS terkait perdagangan jasa, maka setiap negara peserta harus mengambil

${ }^{7}$ R. Winantyo, dkk. Global. Jakarta: PT Elex Media Komputindo, Masyarakat Ekonomi Asean (2015) Memperkuat Sinergi ASEAN di Tengah Kompetisi, 2008. hlm. 129.

${ }^{8}$ Frankiano B. Randang. Kesiapan Tenaga Kerja Indonesia dalam Menghadapi Persaingan dengan Tenaga Kerja Asing. Servanda Jurnal Ilmiah Hukum, 5(1), 2011, hlm. 67.

${ }^{9}$ FX. Joko Priyono. Hukum Perdagangan Jasa (GATS/WTO). Semarang: Badan Penerbit Universitas Diponegoro, 2010, hlm. 99.

10Ibid, h.lm 100.

Junia Adolfina Blegur Laumuri, Transformasi Pengaturan Perdagangan Jasa Perawat : Perspektif GATS Berdasarkan Undang-Undang Nomor 38 Tahun 2014 Tentang Keperawatan 
segala upaya dan tindakan untuk menjamin ditaatinya ketentuan-ketentuan perjanjian internasional ini oleh badan-badan dan pejabat-pejabat pemerintah daerah dan lokal dan badan non pemerintah di dalam wilayahnya, sebagaimana diatur dalam Pasal I ayat (3) GATS, measures by Members dalam perjanjian ini dimaksudkan dengan segala tindakan yang diambil oleh: (1) Pemerintah pusat, daerah, lokal, dan pejabat-pejabat negara peserta, dan ( 2 badan-badan hukum bukan pemerintah yang melaksanakan wewenang yang didelegasikan kepada mereka oleh pemerintah pusat, regional atau lokal atau pejabat-pejabatnya.

Dalam GATS ada empat ketentuan yang diberlakukan secara umum yang sangat penting, yaitu:

\section{Most-Favoured-Nation Treatment atau MFN (Article II GATS)}

Berdasarkan Article II paragraph (1) yang mengatur ketentuan terkait MFN setiap anggota harus segera dan tanpa syarat kepada jasa dan penyedia jasa dari setiap perlakuan anggota lainnya yang tidak kurang menguntungkan daripada yang ia sepakati untuk sama seperti jasa dan penyedia jasa dari negara lain mana pun. ${ }^{11}$ Bahwa ketentuan ini merupakan ketentuan yang mensyaratkan adanya perlakuan sama (no less favourable) yang harus diberikan dengan segera dan tanpa syarat ${ }^{12}$ baik kepada jasa maupun penyedia jasa dari negara sesama anggota WTO sebagaimana diberikan perlakuan kepada penyedia jasa dari negara lainnya.

Namun, GATS memberikan kemungkinan bagi negara-negara anggota untuk merubah komitmen Most-Favoured-Nation Treatment (MFN) mereka dengan melakukan pengecualian berdasarkan Annex on Article II Exemptions. ${ }^{13}$ Ketentuan MFN dalam GATS juga melarang adanya resiprositas (timbal balik) sepanjang resiprositas tersebut diberlakukan kepada penyedia jasa asing. Oleh karena itu sangatlah penting jika seandainya suatu negara mengecualikan diri dari ketentuan MFN, maka asosiasi jasa di negara tersebut tidak akan dapat memberlakukan persetujuan resiprositas dengan asosiasi jasa dari negara lain untuk bisa memberikan askses pasar kepada pemasok jasa mereka atau menggunakan syarat resprositas sebagai syarat untuk bisa masuk.

${ }^{11}$ Djoni Satriana. (Pengaturan Perdagangan Jasa Dalam Hukum Ekonomi Internasional, Jurnal Surya Kencana Dua: Dinamika Masalah Hukum dan Keadilan, 3(1), 2016, hlm. 110-111.

${ }^{12}$ Hendra Djaja.. Penegakan Prinsip Special And Differential Treatment Dalam Persepektif Hukum Perdagangan Internasional. Jurnal Cakrawala Hukum, 19(1), 2014, hlm. 20.

13FX. Joko Priyono, op.cit, hlm. 101.

Junia Adolfina Blegur Laumuri, Transformasi Pengaturan Perdagangan Jasa Perawat : Perspektif GATS Berdasarkan Undang-Undang Nomor 38 Tahun 2014 Tentang Keperawatan 
Ada tiga kondisi atau situasi di mana MFN ini dapat tidak diterapkan, pertama, terdapat negara-negara yang mengecualikan diri dari MFN, kedua, Article VII GATS mengizinkan negara anggota WTO melakukan perundingan mengenai MRA bersama negara lain namun harus ada pemberitahuan kepada WTO pada awal perundingan, dan tiap-tiap negara anggota harus memiliki keinginan untuk menawarkan MRA tersebut kepada negara anggota WTO lainnya, ketiga, Pasal V GATS mengizinkan adanya perlakuan yang berbeda yang berhubungan dengan perjanjian maupun kesepakatan intergrasi ekonomi. ${ }^{14}$

\section{Transparency (Pasal III GATS)}

Transparansi diatur dalam Article III GATS yang mewajibkan serta mengharuskan semua anggota WTO untuk mempublikasikan semua peraturan perundangan-undangan, dan peraturan ataupun pedoman pelaksanaan, serta semua keputusan dan ketentuan yang berlaku secara secara umum yang berdampak ataupun terkait terhadap perdangan jasa yang dikeluarkan oleh pemerintah pusat maupun daerah termasuk mengenai limitation maupun restriction ${ }^{15}$ yang berdampak terhadap pelaksanaan GATS. Selain itu, negara anggota WTO juga diharuskan dan diwajibkan untuk memberitahukan hal-hal terat perdagangan jasa khususnya dalam tulisan ini perdagangan jasa perawat kepada Dewan Perdagangan Jasa (Council for the Trade and Service) minimal setahun sekali. ${ }^{16}$

\section{Domestic Regulation (Pasal VI GATS)}

Article VI GATS mengatur mengenai regulasi atau peraturan perundang-undangan domestik, yang termasuk dalam regulasi domestik adalah aturan-aturan suatu negara mengenai lisensi dan kualifikasi bagi para pemasok jasa mereka sendiri. Ketentuan ini memiliki enam ayat dan hanya satu ayat yang dapat diberlakukan secara umum kepada semua negara anggota WTO yaitu Pasal VI ayat 2 GATS. Dalam ketentuan ini meminta pada semua anggota WTO untuk membuat prosedur yang obyektif dan tidak memihak (impartial) tentang segala keputusan negatif oleh suatu negara yang melarang pemasok jasa asing misalnya perawat, advokat atau akuntan asing. Untuk menutupi keadaan itu maka, Pasal VI ayat 2 GATS secara tegas

14 Ibid, hlm. 101-102.

${ }^{15}$ Alberta Hartiana. Prinsip-Prinsip GATS (General Agreement On Trade In Services) Terhadap Perdagangan Jasa Pendidikan Tinggi. Jurnal Magister Hukum Udayana, 5(4), 2016, hlm. 763.

${ }^{16}$ H.S. Kartadjoemena. GATT dan WTO (Sistem, Forum dan Lembaga Internasional dibidang perdagangan). Jakarta: UI-Press, 2002,hlm.191-192.

Junia Adolfina Blegur Laumuri, Transformasi Pengaturan Perdagangan Jasa Perawat : Perspektif GATS Berdasarkan Undang-Undang Nomor 38 Tahun 2014 Tentang Keperawatan 
menyatakan bahwa hal itu tidak berlaku jika bertentangan dengan konstitusinya atau sistem hukumnya. ${ }^{17}$

\section{Recognition (Pasal VII GATS)}

Pengakuan (recognition) sebagaimana diatur dalam Article VII GATS dapat diatasi melalui MRA atau persetujuan pengakuan bersama. Berdasarkan ketentuan Article VII paragraph 5 GATS, dimana pengakuan harus didasarkan pada persyaratan-persyaratan yang disetujui secara multilateral. Organisasi antar pemerintah atau non pemerintah diharapkan dapat bekerjasama dengan negara anggota WTO untuk dapat membentuk dan menggunakannya standarisasi internasional yang sama dan setara terkait praktek perdagangan jasa dan profesi yang relevan. Persetujuan pengakuan bersama merupakan jalan terbaik untuk menghindari aturan MFN, hal ini karena bila negara anggota melakukan persetujuan pengakuan bersama dengan negara lainnya (bilateral, multilateral, dan regional) maka harus member kesempatan kepada semua negara anggota WTO untuk berpartisipasi dalam sebuah persetujuan pengakuan bersama. Selain itu persetujuan pengakuan bersama harus diberitahukan terlebih dahulu kepada Sekretariat WTO.

Pengaturan liberalisasi perdagangan jasa kesehatan khususnya perawat secara eksplisit diatur dalam ketentuan GATS. Sebagaimana ketentuan Article 1 GATS, perdagangan jasa perawat antar negara-negara anggota WTO merupakan suatu hal yang diperbolehkan dan dapat dilakukan dengan memenuhi prinsip-prinsip yang diatur dalam GATS, yaitu:

a) terkait dengan perdagangan jasa di bidang jasa kesehatan khususnya keperawatan bahwa perlakuan yang sama harus didapatkan oleh semua negara anggota.

b) dengan menghapus mengahruskan negara-negara meniadakan atau menhapus aturan-aturan yang menjadi hambatan-hambatan bagi perawat asing untuk mengakses pasar sektor jasa keperawatan di negara-negara anggota adalah sebagai upaya untuk melaksanakan liberalisasi perdagangan jasa secara progresif. Prinsip ini dalam GATS dikenal dengan prinsip market access sebagaimana yang diatur dalam Article XVI. Berdasarkan prinsip ini juga maka tidak diperbolehkan menghambat masuknya perawat asing ke dalam pasar domestik.

Segala tindakan maupun aturan-aturan yang berkaitan dengan persyaratan mengenai standar kuaifikasi maupun prosedur ataupun standar teknis dan lisensi tidak boleh dijadikan suatu halangan yang dapat menghambat dalam perdagangan jasa sebagaimana yang diatur dalam Article VI paragraph (4) GATS. Untuk itu antar negara-negara anggota WTO dapat dan diperbolehkan untuk membuat MRA, di mana negara anggota ASEAN

17FX. Joko Priyono, op.cit., hlm. 103.

Junia Adolfina Blegur Laumuri, Transformasi Pengaturan Perdagangan Jasa Perawat : Perspektif GATS Berdasarkan Undang-Undang Nomor 38 Tahun 2014 Tentang Keperawatan 
memiliki hak dan kewajiban yang sama sesuai MRA, 18 dengan tujuan meminimalkan perbedaan-perbedaan dalam menentukan kualifikasi, standarisasi dan/atau lisensi berdasarkan Article VII GATS, dimana dalam ketentuan Article VII GATS ini juga dimaksudkan sebagai jembatan atas perbedaan konsep dasar yang diatur dalam GATS dengan konsep dasar peraturan domestik dari suatu negara, dimana hal ini diakibatkan karena terdapat perbedaan kondisi tiap-tiap negara khususnya yang berkaitan dengan keperawatan maupun profesi perawat. Secara teoritis, oleh karena stakeholders pada perdagangan khususnya perdagangan jasa internasional mencakup tidak hanya nasional tetapi juga internasional sebagaimana kebebasan pasar yang dikemukakan oleh Adam Smith, hal ini dimaksudkan agar peran negara dan peran pasar dapat berjalan secara paralel. Oleh karena itu, diharapkan perbedaan konsep dasar yang diatur berdasarkan ketentuan hukum internasional dengan ketentuan hukum domestik dapat diminimalisir dan semakin mengerucut. ${ }^{19}$

\section{Transformasi Asean Mutual Recognition Arrangement On Nursing Services dalam Undang-Undang Nomor 38 Tahun 2014 Tentang Keperawatan}

MRA merupakan realisasi dari Article 5 Perjanjian AFAS dimana MRA mengatur 2 (dua) hal pokok yakni, MRA dibidang barang (MRA in trade of Goods) dan MRA dibidang Jasa (MRA in trade of Services) dan dalam MRA in trade of Services mengatur mengenai kualifikasi tenaga profesional dibidang pelayanan jasa dengan tujuan mempermudah dengan memfasilitasi perpindahan dan mekanisme pasar tenaga profesional termasuk buruh yang terlatih di kawasan negara-negara ASEAN. ${ }^{20}$ Adapun tujuan AFAS antara lain meningkatkan kerja sama di bidang pelayanan khususnya dalam hal ini terkait jasa di antara negara anggota ASEAN sehingga dapat meningkatkan keefisienan, persaingan, kapasitas produksi serta menyebarluaskan pelayanan di dalam maupun di luar ASEAN. Selain itu tujuan lainnya adalah untuk menghilangkan hambatan dalam perdagangan pelayanan jasa diantara negara ASEAN dan meliberalkan perdagangan pelayanan jasa baik dengan cara memperluas dan seperti yang tertera dalam tujuan GATS yaitu mewujudkan pasar bebas dalam pelayanan jasa. Pada tanggal 15 Desember 1997 pemimpin-pemimpin negara ASEAN merumuskan ASEAN Vision 2020 dan diharapkan pada tahun 2020 akan terwujud kawasan ekonomi ASEAN yang terus berkompetisi dalam menciptakan kondisi yang stabil dan

${ }^{18}$ Pudjo Utomo. Kesiapan Sumber Daya Manusia (Tenaga Kerja) Bidang Konstruksi di Indonesia Menghadapi Masyarakat Ekonomi ASEAN. Jurnal Ilmiah Ilmu Hukum QISTIE, 7(2), 2014, hlm. 88.

${ }^{19} \mathrm{Ibid}, \mathrm{hlm} .200$.

${ }^{20}$ Rahmi Yuningsih. op.cit. hlm. 186.

Junia Adolfina Blegur Laumuri, Transformasi Pengaturan Perdagangan Jasa Perawat : Perspektif GATS Berdasarkan Undang-Undang Nomor 38 Tahun 2014 Tentang Keperawatan 
kemakmuran bagi semua anggota ASEAN yang diharapkan akan tercapai dengan perdagangan bebas barang, jasa maupun investasi, termasuk kesetaraan dalam pembangunan ekonomi, penurunan angka kemiskinan dan penurunan kesenjangan sosial-ekonomi serta meningkatkan kestabilan politik, ekonomi dan sosial. ${ }^{21}$

Sebagaimana yang telah diuraikan sebelumnya salah satu profesi yang menjadi kesepakatan MRA adalah profesi keperawatan yang dikenal dengan nama MRA on Nursing Services. Dalam Article 2 angka 2.1 MRA on Nursing services, definisi perawat adalah orang yang telah menyelesaikan pelatihan profesional dan memenuhi persyaratan sebagai perawat profesional yang dinilai oleh badan yang mengatur perawat (the Nursing Regulatory Authority of the Country of Origin) baik secara kualifikasi teknik, etik dan legal untuk menangani praktik perawat professional dan telah diregistrasi dan dilisensi sebagai perawat profesional oleh badan yang mengatur perawat, jadi pada pengertian ini tidak dapat diaplikasikan pada perawat teknis. ${ }^{22}$ Menurut Patricia W. Iyer, fungsi perawat khususnya dalam praktik keperawatan terdiri dari fungsi independen, fungsi interdependen dan fungsi dependen. Fungsi independen adalah praktik keperawatan yang dilakukan berdasarkan keilmuan secara mandiri tanpa perintah dokter dan oleh karena itu perawat bertanggung jawab terhadap akibat yang timbul dari keputusan dan tindakannya. Fungsi interdependen adalah praktik keperawatan dilakukan berdasarkan kerja sama antara tim yakni dengan tenaga kesehatan lainnya. Fungsi dependen adalah perawat dalam melakukan tugasnya untuk membantu dokter dalam memberikan pelayanan medis. ${ }^{23}$ Dalam Article 2 angka 2.6 MRA on Nursing services, badan yang ditunjuk untuk mengatur perawat di Indonesia adalah Kementerian Kesehatan Republik Indonesia yang mempunyai kewajiban untuk mengawasi serta membuat peraturan terkait perawat maupun praktik perawat.

Berdasarkan pandangan positivis dalam mengimplementasikan hukum internasional, yang asalnya dari tiap-tiap perjanjian internasional bahwa norma-norma dalam hukum internasional tidak dapat diberlakukan secara langsung dan "ex proprio vigore" diterapkan dalam hukum domestik. ${ }^{24}$ Maka hukum internasional termasuk MRA on nursing services perlu ditransformasi baik secara formal maupun secara substantive dari hukum

21ASEAN. Mutual Recognition Arrangement on Nursing Services, URL: http://www.aseansec.org/19210. htm, diakses tanggal 23 September 2018.

22Joko Gunawan dan Yupin Aungsuroch. ASEAN mutual recognition arrangement for Indonesian nurses: is it a promise?. International Journal of Community Medicine and Public Health. 2(2), 2015, hlm. 78.

${ }^{23}$ Shanti Dwi Kartika, op.cit, hlm. 136. hlm. 101 .

24J.G Strake. (2006). Pengantar Hukum Internasional. Jakarta: Sinar Grafika,

Junia Adolfina Blegur Laumuri, Transformasi Pengaturan Perdagangan Jasa Perawat : Perspektif GATS Berdasarkan Undang-Undang Nomor 38 Tahun 2014 Tentang Keperawatan 
internasional menjadi hukum domestik. ${ }^{25}$ Sehubungan dengan transformasi yang merupakan suatu proses dimana suatu negara yang telah menyetujui dan menandatangani suatu perjanjian internasional wajib menyesuaikan atau mengharmonisasikan sistem hukumnya berdasarkan standar-standar hukum yang telah disepakati dalam suatu perjanjian internasional. Dalam praktek internasional untuk menentukan kapan tepatnya suatu perjanjian internasional berlaku pada suatu negara ditentukan oleh aliran/faham yang dianut oleh negara tersebut, baik aliran dualisme atau aliran monisme. Menurut aliran dualisme, hukum internasional dipandang sebagai tata hukum terpisah secara mutlak dan berada diluar dari hukum nasional dan agar suatu kaedah yang awalnya bersifat hukum internasional dapat berlaku dalam lingkungan hukum nasional maka memerlukan suatu tindakan yang disebut "transformasi". ${ }^{26}$ Sedangkan, menurut aliran monisme, hukum internasional dan hukum nasional pada esensinya dipandang sama-sama menggambarkan bagian dari hukum secara keseluruhan. Oleh karena itu, hukum internasional dipandang berlaku secara "inkorporasi" di lingkungan hukum nasional, tanpa transformasi sebagai hukum nasional. ${ }^{27}$

Hikmanto Juwana berpendapat bahwa terkait dengan ajaran dualisme dan monisme, sesungguhnya bahwa transformasi perjanjian atau aturan internasional ke dalam hukum domestik tidak terikat dengan aliran monisme atau dualisme, kedua aliran tersebut akan ditentukan aliran mana yang akan digunakan apabila ada pertentangan antara hukum domestik dengan hukum internasional. ${ }^{28}$ Dalam konteks Indonesia, lebih jauh Hikmanto mengemukakan bahwa setiap perjanjian atau aturan internasional yang telah ditandatangani dan diratifikasi oleh Indonesia yang mengatur bahwa adanya kewajiban untuk dilaksanakan di tingkat nasional (baik yang diratifikasi atau tidak) perlu untuk ditransformasikan ke dalam hukum domestik atau nasional. ${ }^{29}$

Dengan ditandatanganinya MRA on Nursing services oleh Indonesia ${ }^{30}$ serta guna menghadapi ASEAN Economic Community, pada tahun 2014 Indonesia telah mengundangkan UU Keperawatan. UU Keperawatan ini mengatur tentang ketentuan dengan tujuan untuk memberikan dan

${ }^{25}$ Ibid, hlm. 102.

${ }^{26}$ Ko Swan Sik. Beberapa Catatan atas Permasalahan Treaty di Indonesia. Jurnal Hukum Internasional, 5(3), 2008, hlm. 432.

${ }^{27}$ Ibid.

${ }^{28} \mathrm{Ni}$ Ketut Supasti Darmawan. Hak Kekayaan Intelektual dan Harmonisasi Hukum Global Rekonstruksi Pemikiran Terhadap Perlindungan Program Komputer. Semarang: Badan Penerbit Universitas Diponegoro, 2011, hlm. 59.

${ }^{29}$ Hikmanto Juwana. Catatan atas Masalah Aktual Perjanjian Internasional. Jurnal Hukum Internasional. 5(3), 2008, hlm. 444.

${ }^{30}$ Shanti Dwi Kartika. Urgensi Undang-Undang Tentang Keperawatan. Jurnal Ilmiah Hukum “Negara Hukum”. 3(1), 2012, hlm. 135.

Junia Adolfina Blegur Laumuri, Transformasi Pengaturan Perdagangan Jasa Perawat : Perspektif GATS Berdasarkan Undang-Undang Nomor 38 Tahun 2014 Tentang Keperawatan 
memenuhi perlindungan hukum pada perawat, dengan tujuan untuk meningkatkan mutu pelayanan keperawatan, memberikan pelindungan hukum dan kepastian hukum kepada perawat, meningkatkan kualitas tenaga kerja perawat, dan meningkatkan taraf kesehatan masyarakat termasuk perawat dan pasien dalam kaitannya dengan perdagangan jasa perawat sebagaimana ketentuan yang diatur dalam MRA on Nursing services. Sedangkan, dalam hal kelembagaan, UU Keperawatan mengamanatkan untuk pembentukan beberapa lembaga diantaranya Kolegium Keperawatan dan Konsil Keperawatan, dimana kedua lembaga tersebut mempunyai fungsi utama dalam peningkatan kualitas keperawatan Indonesia dan pengawasan serta pembinaan perawat-perawat di Indonesia. Berdasarkan Pasal 49 ayat (2) UU Keperawatan huruf a mengatur bahwa konsil keperawatan bertugas untuk melakukan registrasi terhadap perawat, dan berdasarkan tugas tersebut konsil keperawatan berwenang untuk menolak ataupun menyetujui permohonan registrasi perawat Indonesia termasuk perawat asing dimana hal ini diatur dalam Pasal 50 huruf a UU Keperawatan, berdasarkan kedua ketentuan pasal tersebut dapat dilihat bahwa fungsi dan kewenangan konsil keperawatan di Indoensia merupakan hal yang sangat penting.

Terkait dengan perdagangan jasa perawat, adapun persyaratan mengenai perdagangan jasa perawat dalam MRA on nursing services yang harus dipenuhi oleh perawat yang akan bekerja diluar negeri (khususya dalam negara-negara anggota ASEAN) adalah perawat telah diregistrasi di negara asal dan telah memiliki lisensi untuk berpraktik keperawatan. Selain itu, perawat juga harus diregistrasi dan dilisensi di negara tujuan kerja sebagai syarat agar diakui dan diizinkan untuk melakukan praktik keperawatan berdasarkan dengan peraturan perundang-undangan domestik yang berlaku pada negara tujuan tersebut. Persyaratan lainnya antara lain memenuhi kualifikasi sebagai perawat, sudah teregistrasi atau terlisensi di negara asal, minimal telah berpaktik keperawatan selama 3 (tiga) tahun terakhir, bersedia mengikuti pelatihan keperawatan lanjutan sesuai dengan kebijakan konsil atau badan keperawatan setempat, memiliki sertifikat dari konsil atau badan keperawatan negara asal bahwa perawat tersebut tidak memiliki catatan buruk terkait pelanggaran salam melakukan praktik keperawatan baik secara teknik, standar profesi maupun kode etik dalam tatanan lokal maupun internasional. Selain itu juga harus memenuhi persyaratan lainnya mengajukan pemeriksaan medis, menjalani program adaptasi atau penilaian kompetensi seperti yang ditentukan pada lamaran lainnya terkait registrasi dan lisensi sebagai pertimbangan konsil atau badan keperawatan negara tujuan kerja.

Berdasarkan uraian diatas sudah jelas bahwa tenaga kerja professional khsususnya tenaga perawat asing wajib untuk mengikuti segala

Junia Adolfina Blegur Laumuri, Transformasi Pengaturan Perdagangan Jasa Perawat : Perspektif GATS Berdasarkan Undang-Undang Nomor 38 Tahun 2014 Tentang Keperawatan 
ketentuan dan persyaratan yang ditentukan dalam peraturan perundangundangan termasuk UU Keperawatan untuk dapat bekerja di Indonesia, yaitu perawat asing harus mengikuti evaluasi kompetensi sesuai dengan UU Keperawatan, oleh karena itu perawat asing yang nantinya akan bekerja di Indonesia tidaklah secara otomatis dapat berpraktik di Indonesia. Dalam hal sertifikat kompetensi untuk mahasiswa pendidikan vokasi perawat diberikan sebagai tanda bahwa mashasiswa tersebut telah lulus ujian kompetensi berdasarkan Pasal 16 ayat (5) UU Keperawatan, maka dalam pengaturan pasal tersebut juga dapat di analogikan bahwa perawat asing yang nantinya bekerja di Indonesia juga harus mengikuti ujian kompetensi dan mendapatkan sertifikat kompetensi sebagai tanda kelulusan yang diadakan oleh perguruan tinggi keperawatan di Indonesia. Berdasarkan pengertian perawat pada Article II angka 2.1 MRA on nursing services mengatur secara ekplisit bahwa perawat yang berasal dari salah satu negara anggota ASEAN dapat berpraktik di negara anggota ASEAN lainnya apabila perawat tersebut telah memiliki sertifikat izin praktek yang diterbitkan oleh Nursing Regulatory Authority negara asalnya. Dalam ketentuan yang diatur dalam Article III MRA on nursing services mengatur bahwa perawat asing yang akan bekerja di negara anggota ASEAN maka perawat asing tersebut wajib untuk mengikuti semua persyaratan yang diatur dalam peraturan perundang-undangan yang berlaku di host country. ${ }^{31}$ Dalam hal perawat asing memiliki sertifikat izin praktik dari Nursing Regulatory Authority negara asalnya maka perawat tersebut dapat berpraktik di negara anggota ASEAN.

Berdasarkan teori transformasi hukum tersebut diatas baik terkait kebijakan dalam sertifikasi kompetensi untuk perawat asing di Indonesia berdasarkan Article III MRA on nursing services maka Indonesia diperbolehkan untuk membuat aturan dimana untuk mendapatkan sertifikat kompetensi harus melalui ujian kompetensi yang diselenggarakan dan dikeluarkan oleh perguruan tinggi keperawatan di Indonesia. Setiap perawat asing yang telah melalui proses berdasarkan Pasal 24 ayat (1) UU Keperawatan yakni berupa evaluasi kompetensi di Indoensia dan akan menjalankan praktek di Indonesia maka berdasarkan Pasal 25 ayat (1) UU Keperawatan wajib memiliki Surat Izin Praktik Perawat (SIPP) dan Surat Tanda Registrasi (STR) sementara. STR merupakan bukti tertulis yang diberikan oleh konsil keperawatandimana konsil keperawatan adalah lembaga yang penting dalam melakukan akselerasi kualitas keperawatan Indonesia

Pengaturan lebih lanjut terkait dengan pengawasan dan pembinaan praktik keperawatan yang dilaksanakan salah satunya dilaksanakan oleh

${ }^{31}$ Yemima Amelia Siagian. Perdagangan Internasional Jasa Tenaga Medis Melalui Mutual Recognition Arrangement (MRA) di Kawasan Asean. Journal of International Law, 5(6), 2017. hlm. 1.

Junia Adolfina Blegur Laumuri, Transformasi Pengaturan Perdagangan Jasa Perawat : Perspektif GATS Berdasarkan Undang-Undang Nomor 38 Tahun 2014 Tentang Keperawatan 
konsil keperawatan berdasarkan Pasal 57 UU Keperawatan diatur melalui peraturan menteri. Oleh karena itu, penting segera untuk membuat badan regulator keperawatan yang mandiri di Indonesia untuk menata sistem kredensial bagi perawat (Board of Nursing / Konsil Keperawatan), akan tetapi sampai sekarang konsil keperawatan belum juga terbentuk, meskipun berdasarkan ketentuan Pasal 63 UU Keperawatan seharusnya konsil keperawatan seharusnya dibentuk paling lama pada bulan Oktober tahun 2016. ${ }^{32}$ Belum adanya peraturan teknis dalah hal ini peraturan menteri sebagaimana diatur dalam Pasal 57 UU Keperawatan tersebut maka peran dari konsil keperawatan tidak dapat dilaksanakan secara maksimal baik terkait pembinaan maupun pengawasan praktik keperawatan sehingga dalam hal ini tidak lengkapnya peraturan perundang-undangan terkait pelaksana teknis ketentuan menunjukkan ketidaksiapan pemerintah dalam menghadapi ASEAN Economic Community khususnya perdagangan jasa perawat.

\section{PENUTUP}

Pengaturan liberalisasi perdagangan jasa kesehatan khususnya perdagangan jasa perawat di ASEAN diperbolehkan oleh WTO dengan dibentuknya MRA on nursing services dan dengan keharusan untuk memenuhi prinsip-prinsip yang diatur dalam GATS yang secara eksplisit diatur dalam ketentuan Article I, Article VI ayat (4) dan dalam Article VII GATS. Dengan belum terbentuknya konsil keperawatan di Indonesia tidak hanya mengabaikan ketentuan dalam Pasal 63 UU Keperawatan tetapi juga dapat berpotensi menghambat pelaksanaan MRA on nursing services di Indonesia, karena konsil keperawatan mempunyai wewenang penting dalam memberikan persetujuan atau penolakan atas permohonan registrasi perawat termasuk perawat asing dimana hal ini juga diatur dalam Article III dalam MRA on nursing services, oleh karena itu pelaksanaan transformasi ketentuan tentang perdagangan jasa perawat belum dapat dilakukan secara maksimal sesuai dengan konteks MRA on nursing services.

\section{DAFTAR PUSTAKA}

Alberta Hartiana. 2016. Prinsip-Prinsip GATS (General Agreement On Trade In Services) Terhadap Perdagangan Jasa Pendidikan Tinggi. Jurnal Magister Hukum Udayana, Volume 5, Nomor 4.

Anung Pramudyo.2014. Mempersiapkan Sumber Daya Manusia Indonesia dalam Menghadapi Masyarakat Ekonomi ASEAN Tahun 2015. Jurnal Bisnis Manajemen dan Akuntansi Akademi Manajemen Administrasi YPK Yogyakarta, Volume II, Nomor 2.

${ }^{32}$ Yohanes Hermanto Sirait dan Demson Tiopan. Politik Hukum Pengaturan Profesi Perawat dalam Upaya Standarisasi Masyarakat Ekonomi Asean (MEA). Jurnal IUS, 6(1), 2014, hlm.104.

Junia Adolfina Blegur Laumuri, Transformasi Pengaturan Perdagangan Jasa Perawat : Perspektif GATS Berdasarkan Undang-Undang Nomor 38 Tahun 2014 Tentang Keperawatan 
ASEAN. Mutual Recognition Arrangement on Nursing Services, URL: http://www.aseansec.org/19210. htm, diakses tanggal 23 September 2018.

Djoni Satriana. 2016. Pengaturan Perdagangan Jasa Dalam Hukum Ekonomi Internasional, Jurnal Surya Kencana Dua: Dinamika Masalah Hukum dan Keadilan, Volume 3, Nomor 1.

FX. Joko Priyono, 2010. Hukum Perdagangan Jasa (GATS/WTO). Semarang: Badan Penerbit Universitas Diponegoro.

H.S. Kartadjoemena, 2002. GATT dan WTO (Sistem, Forum dan Lembaga Internasional dibidang perdagangan). Jakarta: UI-Press.

Hendra Djaja. 2014. Penegakan Prinsip Special And Differential Treatment Dalam Persepektif Hukum Perdagangan Internasional. Jurnal Cakrawala Hukum, Volume 19, Nomor 1.

Hikmanto Juwana, 2008. Catatan atas Masalah Aktual Perjanjian Internasional. Jurnal Hukum Internasional. Volume 5, Nomor 3.

Ida Bagus Wyasa Putra, dkk. (2013). Hukum Perdagangan Internasional : Laporan Penelitian, Program Studi Magister (S2) Ilmu Hukum. Denpasar: Universitas Udayana.

Joko Gunawan dan Yupin Aungsuroch, 2015. ASEAN mutual recognition arrangement for Indonesian nurses: is it a promise?. International Journal of Community Medicine and Public Health. Volume 2, Nomor 2.

J.G Strake. 2006. Pengantar Hukum Internasional. Jakarta: Sinar Grafika.

Ko Swan Sik. 2008. Beberapa Catatan atas Permasalahan Treaty di Indonesia. Jurnal Hukum Internasional, Volume 5, Nomor 3.

Makmur Keliat, dkk. 2013. Pemetaan Pekerja Terampil Indonesia dan Liberalisasi Jasa ASEAN. ASEAN Study Center Fakultas Ilmu Sosial dan Ilmu Politik Universitas Indoensia.

Mukti Fajar dan Yulianto Achmad, 2015. Dualisme Penelitian HukumNormatif dan Empiris. Yogyakarta: Pustaka Pelajar.

Ni Ketut Supasti Darmawan. 2011. Hak Kekayaan Intelektual dan Harmonisasi Hukum Global Rekonstruksi Pemikiran Terhadap Perlindungan Program Komputer. Semarang: Badan Penerbit Universitas Diponegoro.

Pudjo Utomo. 2014. Kesiapan Sumber Daya Manusia (Tenaga Kerja) Bidang Konstruksi di Indonesia Menghadapi Masyarakat Ekonomi ASEAN. Jurnal Ilmiah Ilmu Hukum QISTIE, Volume 7, Nomor 2.

Junia Adolfina Blegur Laumuri, Transformasi Pengaturan Perdagangan Jasa Perawat : Perspektif GATS Berdasarkan Undang-Undang Nomor 38 Tahun 2014 Tentang Keperawatan 
R. Winantyo, dkk. 2008. Masyarakat Ekonomi Asean (2015) Memperkuat Sinergi ASEAN di Tengah Kompetisi Global. Jakarta: PT Elex Media Komputindo.

Rahmi Yuningsih. 2012. Dampak Mutual Recognition Arrangement (MRA) on Nursing Services Terhadap Profesi Perawat Indonesia. Jurnal Aspirasi Pusat Pengkajian Pengolahan Data dan Informasi Sekretariat Jenderal DPR RI, Volume 3, Nomor 2.

Shanti Dwi Kartika. 2012. Urgensi Undang-Undang Tentang Keperawatan. Jurnal Ilmiah Hukum "Negara Hukum". Volume 3, Nomor 1.

Solehuddin. 2015. Perlindungan Hukum Terhadap Perawat Dalam Menghadapi ASEAN Economic Community (AEC). Jurnal Hukum Fakultas Hukum Universitas Brawijaya.

Yemima Amelia Siagian. 2017. Perdagangan Internasional Jasa Tenaga Medis Melalui Mutual Recognition Arrangement (MRA) di Kawasan Asean. Journal of International Law, Volume 5, Nomor 6.

Yohanes Hermanto Sirait dan Demson Tiopan, 2014. Politik Hukum Pengaturan Profesi Perawat dalam Upaya Standarisasi Masyarakat Ekonomi Asean (MEA). Jurnal IUS, Volume VI, Nomor 1.

Junia Adolfina Blegur Laumuri, Transformasi Pengaturan Perdagangan Jasa Perawat : Perspektif GATS Berdasarkan Undang-Undang Nomor 38 Tahun 2014 Tentang Keperawatan 